\title{
FORMATION TECHNOLOGY OF PLANAR POLYMER WAVEGUIDE STRUCTURE*
}

\author{
A. Mockutė ${ }^{\mathrm{a}}, \mathrm{R}$. Tomašiūnas ${ }^{\mathrm{a}}$, R. Petruškevičius ${ }^{\mathrm{b}}$, and D. Jucius ${ }^{\mathrm{c}}$ \\ ${ }^{a}$ Institute of Materials Science and Applied Research, Vilnius University, Sauletekio 10, LT-10223 Vilnius, Lithuania \\ E-mail: rolandas.tomasiunas@ff.vu.lt \\ ${ }^{\mathrm{b}}$ Institute of Physics, Savanoriu 231, LT-02300 Vilnius, Lithuania \\ E-mail: raimisp@ktl.mii.lt \\ ${ }^{\mathrm{c}}$ Institute of Physical Electronics, Kaunas University of Technology, Savanoriu 271, LT-50131 Kaunas, Lithuania
}

Received 9 July 2007; revised 18 October 2007; accepted 21 November 2007

\begin{abstract}
Formation technology of planar sub-wavelength ridge polymer waveguides is presented. Second order gratings have been formed at both ends of the waveguides for light coupling from a perpendicularly positioned optical fibre. Reflection spectra of the structure with the first order Bragg grating within central part of the waveguide have been calculated using bidirectional beam propagation method.
\end{abstract}

Keywords: ridge polymer waveguide, mode converters, Bragg gratings

PACS: $42.79 . \mathrm{Gn}$, 42.70.Jk, 42.79.Dj, 42.40.Eq

Photonic integrated circuits would increase performance rate of information processing devices by a factor of 10 compared with electronic integrated circuits used at present. However, the small dimensions of waveguides in photonic circuits create a lot of problems. Coupling of light from an optical fibre to a subwavelength planar waveguide and vice versa is an important issue [1].

A typical diameter of an optical fibre is $4-9 \mu \mathrm{m}$, while the width of a sub-wavelength planar waveguide is $200 \mathrm{~nm}-3 \mu \mathrm{m}$. Large difference in dimensions results in large mode mismatch, which causes low coupling efficiency. Broadened parts (tapers) are formed at the ends of a waveguide, to gradually decrease the large optical fibre mode to the size of polymer ridge waveguide mode [2].

Several methods were proposed to reduce coupling losses between a sub-wavelength polymer ridge waveguide and the outside end-fire coupling with a microlens at the end of an optical fibre, light coupling using prism or second order grating [3]. The latter method is the most attractive. Second order grating has two maxima orders. The second order diffraction maxima are deflected by $90^{\circ}$, when incident light beam is perpendicular to the grating. In this way, light can be

\footnotetext{
* The report presented at the 37th Lithuanian National Physics Conference, 11-13 June 2007, Vilnius, Lithuania.
}

coupled into planar sub-wavelength waveguide by perpendicularly positioned optical fibre implementing second order gratings formed at the end of the waveguide.

Reflection spectra of the structure with the first order Bragg grating have been calculated using bidirectional beam propagation method $[4,5]$. A polymer waveguide without tapers was analysed (width $D=3 \mu \mathrm{m}$, period of Bragg grating $a_{\text {Bragg }}=0.3423 \mu \mathrm{m}$, number of periods $M=200$ ). The effective refractive index of polycarbonate waveguide $n_{\text {eff }}=1.557$ at the wavelength $\lambda=1.064 \mu \mathrm{m}$. Dispersion was not taken into account. The reflection spectrum of the structure, presented in Fig. 1, shows a photonic band gap formed in the range of 1060-1064 $\mathrm{nm}$ (full width at a half maximum - FWHM). For a waveguide with one broadened end (taper length of $M=100$ periods, width at the end $L 3=12 \mu \mathrm{m}$ ) oscillations appear in the reflection spectrum (Fig. 2) due to higher modes supported by the relatively wide taper. Due to the excitation of higher modes a redistribution of intensity between main mode and oscillations appears (the signal in Fig. 1 is higher in respect to Fig. 2). In addition, the Bragg grating formed within the taper creates chirped grating effect due to change of the effective index of tapered waveguide. When the grating is removed from the taper, the additional oscillations disappear (Fig. 3). However, the band gap broadens till the range of 1057-1067 nm. 


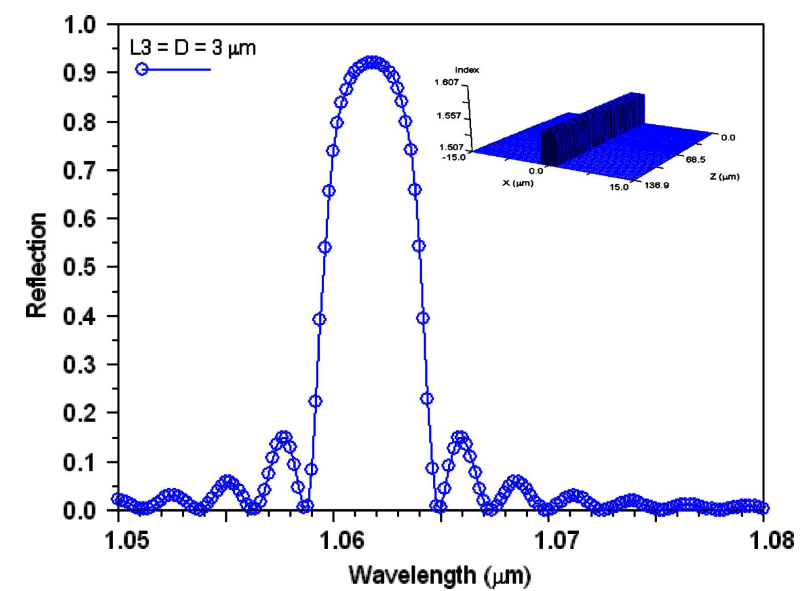

Fig. 1. Reflection spectrum of the polycarbonate waveguide without tapers. The first order Bragg grating is formed within the entire structure.

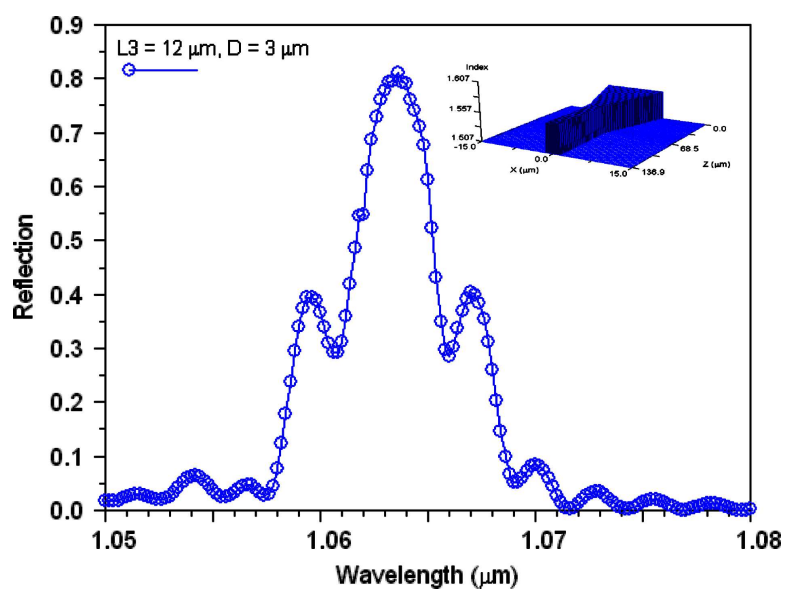

Fig. 2. Reflection spectrum of the polycarbonate waveguide with a taper. The first order Bragg grating is formed within the entire structure.

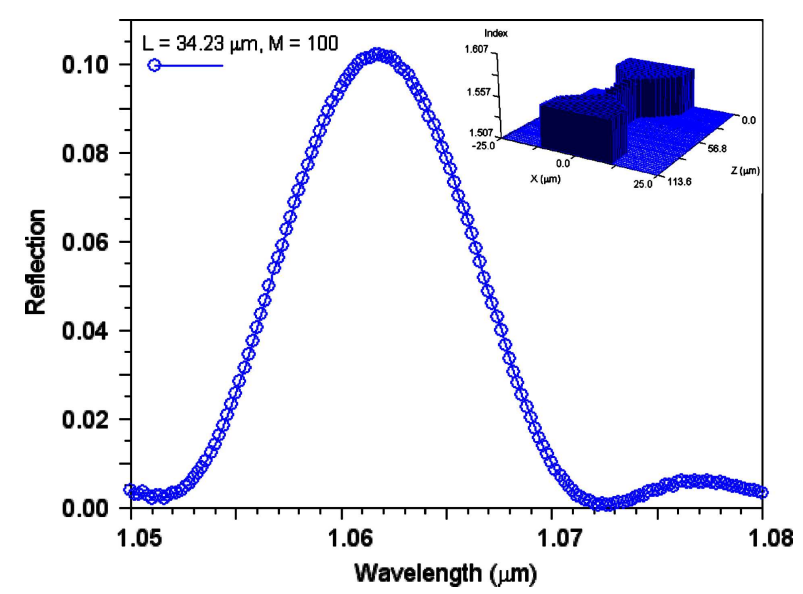

Fig. 3. Reflection spectrum of the polycarbonate waveguide with tapers. The first order Bragg grating is formed only within the central part.

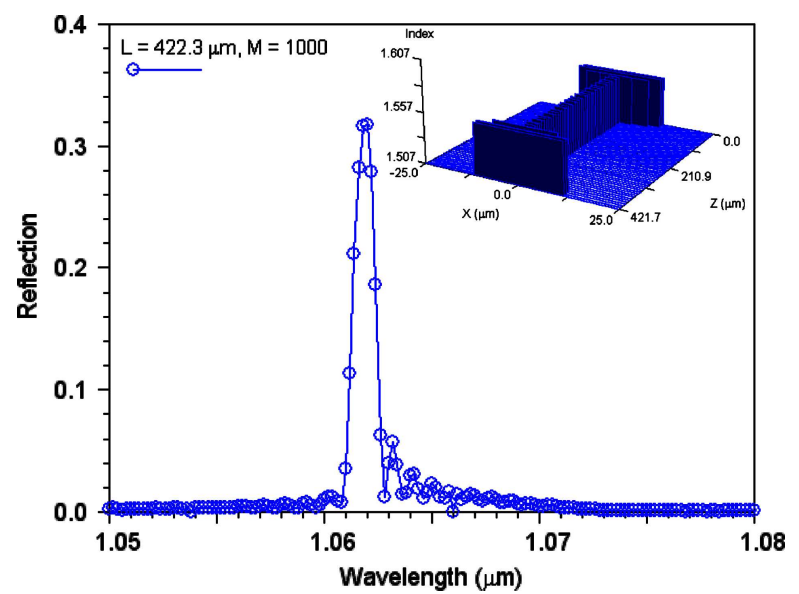

Fig. 4. Reflection spectrum of the polycarbonate waveguide with tapers and longer central part. The first order Bragg grating is formed only within the central part.

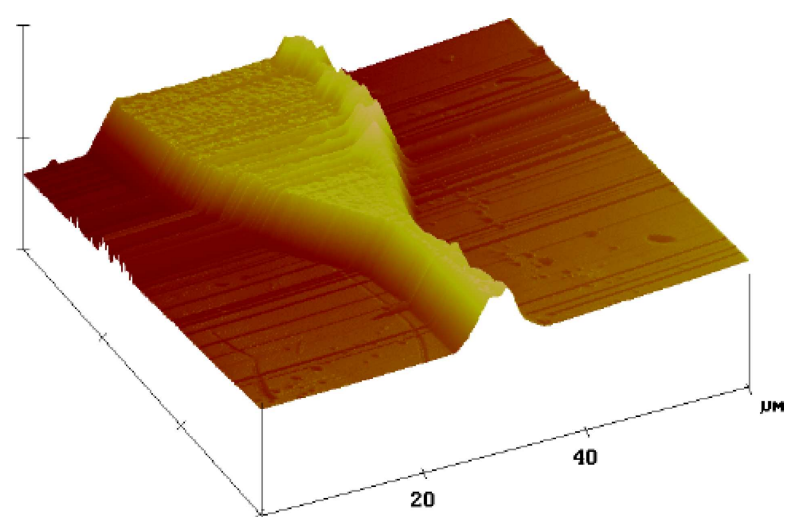

Fig. 5. AFM image of the polymer ridge waveguide with taper mode converter fabricated by nanoimprint lithography technique. The height of waveguide structure is $1.919 \mu \mathrm{m}$.

The reflection spectra can be further improved (narrowing the band gap till the range of 1061-1062.5 nm) by forming the central part of the waveguide longer $(M=$ 1000 periods, Fig. 4), supposing a suppressed influence of the tapers.

Samples were prepared as follows: glass plates used as substrates were degreased in ethanol, washed in distilled water, and dried. $200 \mathrm{mg}$ polycarbonate Iupilon Z-200 was solved in $2.5 \mathrm{ml}$ tetrahydrofurane, $20 \mathrm{mg}$ disperse red 19 (DR 19) azo-dye was added. In order to increase DR19 solubility, the mixture was heated at $80^{\circ} \mathrm{C}$ for $15 \mathrm{~min}$. Refractive index $n$ of polycarbonateDR19 guest-host system can be changed by varying DR19 concentration. Maximum dye concentration is $10 \%$, which corresponds to $n=1.59$. Thin azopolymer layers were spin-coated on the glass plates. Nanoimprint lithography technique was employed to form the waveguides. Inspection of the waveguides 


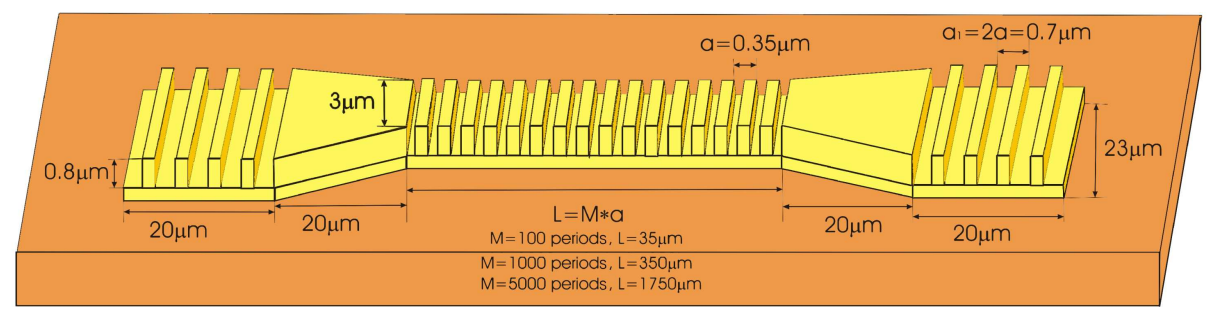

Fig. 6. Calculated passive polymer waveguide filter.

was performed by atomic force microscope (AFM, Fig. 5). Images revealed that lateral dimensions corresponded to theoretically defined ones. The dimensions of waveguides (Fig. 6) supporting propagation of a single mode Gaussian beam of $\lambda=1064 \mathrm{~nm}$ were calculated theoretically using imaginary distance beam propagation method. The width of the central part of the waveguide was $3 \mu \mathrm{m}$. The structure can serve as a waveguide filter, if the first order Bragg grating is formed within the waveguide (see Fig. 1). Azo-dye DR19 can be used to create non-centrosymmetric media for second harmonic generation inside the waveguide and electro-optic tuning of Bragg grating band gap.

Second order gratings at both ends of the waveguides were inscribed using interference lithography technique. Single pulses of $\tau \sim 30$ ps duration were selected from a train of pulses produced by a mode-locked YAG: $\mathrm{Nd}^{3+}$ laser. Second harmonic $(\lambda=532 \mathrm{~nm})$ beam was split by a beam splitter into two of the same intensity, which impinged with an angle $2 \Theta$ on the surface of the sample, creating an interference pattern. Periodicity of the grating was calculated using formula $\Lambda=\lambda / 2 \sin \Theta$. The grating period can be easily changed by varying the angle between intersecting laser beams or by using different wavelength. Interference lithography technique is a very attractive, flexible, and cheap technique to form gratings since it ensures good quality over a wide period range.

Pure polycarbonate is transparent in the visible spectrum. Polycarbonate with electro-optic azo-dye DR19 has an absorption maximum at $496 \mathrm{~nm}$ which ensures absorption of the laser light and recording of the surface relief grating.

In our experiment gratings were inscribed into the polymer via ablation process. No resist was used, thus additional resist spin-coating, development, and removal procedures were avoided.

Gratings with periods in the range of $0.7-5 \mu \mathrm{m}$ were formed in the azo-polymer layer. Optical microscope images and diffraction experiments demonstrated good quality of the gratings and showed that

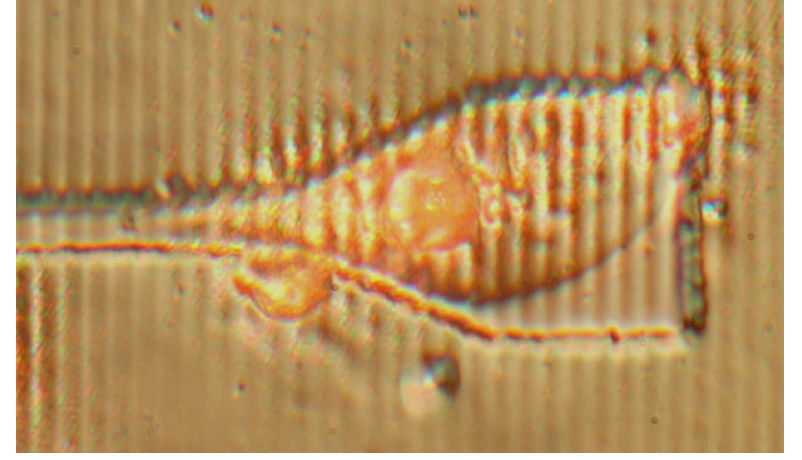

Fig. 7. Optical microscope image of the waveguide. Grating of period $2.5 \mu \mathrm{m}$ formed within the taper of the waveguide.

periods agree with the expected values. Gratings with periods of $2.5 \mu \mathrm{m}$ were inscribed within the tapers of polycarbonate-DR19 waveguides (Fig. 7). The disadvantage of interference lithography technique is that grating is formed in a slightly larger area than required. This will cause oscillations in the reflection spectrum of the structure, as it has been shown in theoretically calculated spectra (Fig. 2).

In conclusion, formation technology possiblities for planar polymer waveguides with second order Bragg gratings for light coupling are presented. Mechanical and optical properties of polycarbonate with dye DR19 confirmed suitability of the material for planar subwavelength waveguide structures. AFM images have revealed that planar dimensions of the waveguides are in good agreement with the theoretically expected values. Optical microscope inspection along with diffraction experiments showed good quality of the gratings formed. Theoretical modelling demonstrated reflection spectra dependence on the structure parameters.

\section{Acknowledgements}

We would like to thank P. Adomenas for dye synthesis, G. Medeišiene for fabricating the samples, V. Kubilius for AFM pictures, Z. Balevičius for polymer layer ellipsometric characterization. This work was supported in part by the Lithuanian State Science and Studies Foundation, Agency for International Science 
and Technology Development Programmes in Lithuania, and EU COST P11 Action.

\section{References}

[1] P. Sanchis, J. Marti, P. Dumon, P. Bienstman, and R. Baets, Analysis and design of efficient coupling in photonic crystal circuits, Opt. Quantum Electron. 37(1-3), 133-147 (2003).

[2] P. Bienstman, S. Assefa, S.G. Johnson, J.D. Joannopoulos, G. Petrich, and L. Kolodziejski, Taper structures for coupling into photonic crystals slab waveguides, J. Opt. Soc. Am. B 20(9), 1817-1821 (2003).

[3] D. Taillaert, F.V. Laere, M. Ayre, W. Bogaerts, D.V. Thourhout, P. Bientsman, and R. Baets, Grating couplers for coupling between optical fibers and nanophotonic waveguides, J. Appl. Phys. 45(8A), 60716077 (2006).

[4] R. Scarmozzino, A. Gopinath, R. Pregla, and S. Helfert, Numerical technigues for modeling guided-wave photonic devices, IEEE J. Sel. T. Quantum Electron. 6(1), 150-162 (2000).

[5] R. Petruskevicius, BiBPM modeling of slow wave structures, Opt. Quantum Electron. 39(4-6), 407-418 (2007).

\title{
PLOKŠČIO POLIMERINIO BANGOLAIDINIO DARINIO FORMAVIMO TECHNOLOGIJA
}

\author{
A. Mockutè ${ }^{\mathrm{a}}$, R. Tomašiūnas ${ }^{\mathrm{a}}$, R. Petruškevičius ${ }^{\mathrm{b}}$, D. Jucius ${ }^{\text {c }}$ \\ ${ }^{a}$ Vilniaus universiteto Medžiagotyros ir taikomuju mokslų institutas, Vilnius, Lietuva \\ ${ }^{\mathrm{b}}$ Fizikos institutas, Vilnius, Lietuva \\ ${ }^{\mathrm{c}}$ Kauno technologijos universiteto Fizikines elektronikos institutas, Kaunas, Lietuva
}

\section{Santrauka}

Aprašoma nauja plokščiu polimerinių mažesnių už bangos ilgi bangolaidžių formavimo technologija. Nanoịspaudimo būdu suformuoti polikarbonato su DR19 dažu juosteliniai bangolaidžiai, kurių modų lūžio rodikliai teoriškai ivvertinti menamos krypties pluošto sklidimo metodu. Gardelès šviesos ịvedimui užrašytos naudojant interferencinę abliaciją. Darinio su pirmos eilès Brego gardele centrinejje dalyje atspindžio spektras teoriškai modeliuotas taikant dviejų krypčių pluošto sklidimo metodą. Gauti spektrai patvirtino siauros fotoninès draustinès juostos susiformavimą esant ilgiems juostelinio bangolaidžio kanalams. 